\title{
Paulina Suchodolska
}

e-mail: suchodolska26@gmail.com

\section{Agnieszka Orkusz}

Uniwersytet Ekonomiczny we Wrocławiu

e-mail: agnieszka.orkusz@ue.wroc.pl

ORCID: 0000-0001-5394-7407

\section{OTYŁOŚĆ - PRZYCZYNY, RODZAJE, LECZENIE, SKUTKI}

\section{OBESITY - CAUSES, TYPES, TREATMENT, EFFECTS}

DOI: 10.15611/nit.2018.4.04

JEL Classification: I10

Streszczenie: Otyłość jest aktualnie uważana za jeden z najbardziej krytycznych problemów zdrowotnych na świecie. Z każdym rokiem dotyczy on rosnącej populacji w krajach europejskich, również w Polsce. Istnieje wiele dowodów na wpływ otyłości na inne jednostki chorobowe, takie jak cukrzyca typu II, choroba niedokrwienna serca, nowotwory. Styl życia, w połączeniu z szybkim rozwojem nowych technologii, powoduje, że ludzie stają się wygodniejsi, chętniej jedzą poza domem, często wprowadzając do swojego życia diety zawierające nadmierną ilość energii. Zła dieta w połączeniu z brakiem aktywności fizycznej jest głównym czynnikiem prowadzącym do nadwagi i otyłości. Celem artykułu było przedstawienie wybranych aspektów otyłości, tj. czynników na nią wpływających, jej rodzajów, metod leczenia oraz skutków.

Słowa kluczowe: otyłość, nadwaga, epidemia, choroby cywilizacyjne.

Summary: Obesity is considered one of the most critical health problems in the present world. Every year this problem concerns the growing population in European countries as well as in Poland. There is much evidence for the effects of obesity on other disease entities such as type II diabetes, coronary heart disease, and cancer. The current lifestyle, combined with the rapid development of new technologies, makes people more comfortable, eager to eat outside, often introducing diets containing excessive amounts of energy into their lives. An inadequate diet, combined with a lack of physical activity is a significant factor leading to overweight and obesity. The work aims to present selected aspects of obesity, i.e. factors affecting obesity, its types, treatment methods and effects of obesity.

Keywords: obesity, overweight, epidemic, civilization diseases. 


\section{Wstęp}

Otyłość jest zdefiniowana jako nadmierne nagromadzenie tkanki tłuszczowej, prowadzące do licznych powikłań narządowych i stanowiące zagrożenie zdrowia człowieka. W 1997 r. Światowa Organizacja Zdrowia ogłosiła, że otyłość jest schorzeniem, które występuje na niespotykanie dużą skalę, stanowiąc jedno z najbardziej niebezpiecznych zagrożeń zdrowia i życia. Otyłość, zarówno u dzieci, jak i osób dorosłych, wynika m.in. z nadmiernej podaży kalorii, uwarunkowania genetycznego, czynników środowiskowych i psychologicznych. W ostatnich dekadach nastąpiły znaczne zmiany w zachowaniu dzieci, polegające na zmniejszeniu ich aktywności fizycznej i zwiększeniu siedzącego trybu życia, co w ogromnym stopniu przyczyniło się do zwiększenia liczby osób z nadwagą i otyłością.

\section{Wybrane czynniki wpływające na otyłość}

\subsection{Czynniki biologiczne}

Wśród biologicznych uwarunkowań otyłości wymienia się m.in.: czynniki o podłożu genetycznym, zaburzenia kliniczne oraz środki farmakologiczne powodujące nieprawidłowości w metabolizmie.

Czynniki genetyczne odgrywają znaczną rolę wśród uwarunkowań biologicznych, które determinują występowanie otyłości. Dziedziczenie otyłości szacuje się na poziomie około 33\% (Mazur, Szymanik, Matusik i Małecka-Tendera, 2006). Występuje ono głównie w charakterze poligenicznym takim, w którym za determinację jednej cechy odpowiada kilka genów. Jeśli jedno z rodziców jest otyłe, ryzyko zachorowania dziecka na tę przypadłość wzrasta 4-5-krotnie, a gdy schorzenie to dotyka obojga rodziców, ryzyko wzrasta aż 13-krotnie (Pietrzykowska i Wierusz-Wysocka, 2008). Należy jednak pamiętać, że dziedziczenie w tym przypadku polega jedynie na dziedziczeniu skłonności do otyłości, a nie rozwoju tej choroby w momencie zapłodnienia (Ogińska-Bulik, 2007).

Do przyrostu tkanki thuszczowej w organizmie mogą się przyczyniać genetycznie uwarunkowane zespoły, np. Downa, Lawrence'a-Moona-Bielda, Williego-Pradera czy Turnera (Juruć i Bogdański, 2011).

Do zaburzeń klinicznych należą głównie: nowotwory, neuroinfekcje, zaburzona praca gospodarki hormonalnej (pierwotna i wtórna niedoczynność tarczycy, niedobór testosteronu, karłowatość przysadkowa, zespół policystycznych jajników, zespół Cushinga, tętniaki, wady rozwojowe, wielotorbielowatość jajników (Juruć i Bogdański, 2011)).

Czynnikiem sprzyjającym przyrostowi tkanki tłuszczowej jest przyjmowanie środków farmakologicznych, które często są nieodłącznym elementem leczenia różnych jednostek chorobowych. Leki zawierające składniki, takie jak estrogeny czy progesteron, leki przeciwdepresyjne, przeciwpadaczkowe, insulina czy glikokorty- 
kosteroidy znacznie wpływają na funkcjonowanie organizmu (Czerwińska, Walicka i Marcinowska-Suchowierska, 2013). Leki te z reguły nie powodują tycia, lecz mogą prowadzić do zaburzeń gospodarki hormonalnej, wodno-elektrolitowej i lipidowej, a także wywoływać skutki mające wpływ na nadmierne przybieranie na masie. Niektóre leki mogą wyzwalać uczucie ciagłego zmęczenia i senności, doprowadzające do znacznego ograniczenia aktywności fizycznej. Inne z kolei zaburzają przemianę metaboliczną organizmu lub wyzwalają ciagłe uczucie głodu, kolejne zaś są odpowiedzialne za nadmierne zatrzymywanie wody w organizmie.

\subsection{Czynniki psychologiczne}

Wśród psychologicznych uwarunkowań otyłości wyróżnia się m.in.: trudności z wyrażaniem emocji, problemy w radzeniu sobie ze stresem, przekonania i oczekiwania wobec własnej osoby (Ogińska-Bulik, 2007).

Ludzie mają pewne oczekiwania wobec siebie i otaczającego świata. Często są krytyczni względem siebie, cechując się niskim poczuciem własnej wartości, pesymizmem, postrzegają siebie negatywnie. W wielu przypadkach jednostka chcąca poradzić sobie z problemem, który wywołuje złe emocje, sięga po jedzenie, w konsekwencji czego często ma poczucie winy. Osoby działające w ten sposób zazwyczaj chcą to zmienić, bo mają poczucie, że nie mogą się dłużej objadać. Zjawisko to najczęściej występuje u osób z nadwagą. Człowiek narzuca sobie negatywne myślenie, ponieważ ciagle w myślach słyszy słowo „muszę!” i znów, próbując zabić poczucie winy, zaczyna podjadać. W ten sposób błędne koło się zamyka (Ogińska-Bulik, 2004).

Dla wielu ludzi problem objadania pojawia się pod wpływem stresu. Mówi się nawet, że ludzie „połykają” swoje emocje. Podczas stresu w ciele ludzkim zachodzą zmiany fizjologiczne, takie jak m.in.: nadmierna potliwość, uciskanie klatki piersiowej i brzucha, omdlenia czy też przyśpieszone bicie serca. Niejednokrotnie odbierane są one jako uczucie głodu, co powoduje zwiększenie ilości jedzenia, po które się sięga (Kłósek, 2016).

W związku z problemami w radzeniu sobie z przeżywanymi emocjami nadmierne spożywanie zbyt dużych porcji posiłków może być formą manifestu czy też zwrócenia na siebie uwagi (Pietrzykowska i Wierusz-Wysocka, 2008). Osoby otyłe wielokrotnie spotykają się z odrzuceniem przez społeczeństwo, co znacznie wpływa na ich złe samopoczucie i niską samoocenę. Nawiązywanie relacji międzyludzkich staje się dla nich utrudnione z powodu braku samoakceptacji. Osoby otyłe często zamykają się w sobie i wychodzą z domu tylko wówczas, gdy jest to konieczne (Morawska i in., 2015). W dzisiejszych czasach, gdy na portalach społecznościowych wykreowany jest trend posiadania sylwetki fit, zbędne kilogramy traktowane są jak przekleństwo. Względem ludzi z nadwagą pojawia się wrogość, zwana hejtem, co sprawia, że otyli coraz częściej i chętniej sięgają po kolejne porcje jedzenia.

Cechy osobowości osób otyłych nie są istotnie odmienne od cech osób o masie ciała zgodnej z normami. Jednakże inaczej jest, jeśli chodzi o zmienne behawioralne 
dotyczące wagi, prawidłowego postrzegania swojego obrazu i sposobu odżywiania. Osoby z odpowiednią masą ciała znacznie rzadziej niż o osoby otyłe zwracają uwagę na to, ile jedzą, jak wyglądają i ile ważą. Chcąc kontrolować swój wygląd, ludzie otyli często starają się ograniczać jedzenie do minimum, aby szybko schudnąć, co powoduje, że dostają ataku kompulsywnego jedzenia i tyją jeszcze szybciej (Brytek-Matera i Charzyńska, 2009).

\subsection{Czynniki środowiskowe}

Do podstawowych czynników środowiskowych wpływających na nadmierne spożycie pokarmów zalicza się na pierwszym miejscu nieprawidłowy styl odżywiania. Często oparty jest on na naśladownictwie. Rodzice przekazują dziecku swój sposób odżywiania (jakość i ilość spożywanych produktów). Dziecko w ten sposób podporządkowuje się do obowiązujących w domu zasad i zwyczajów żywieniowych, co w wielu przypadkach skutkuje stosowaniem ich w dorosłym życiu. Od najmłodszych lat rodzice, chcąc jak najlepiej zadbać o rozwój dziecka, podsuwają mu przeróżne smakołyki, aby „dobrze wyglądało”. Doprowadzają do sytuacji, że żołądek dziecka jest w stanie przyjąć większą ilość pokarmów, co w późniejszych etapach rozwoju dziecka może prowadzić do spożywania nadmiernej ilości jedzenia (Ogińska-Bulik, 2004).

Najbardziej istotną determinantą otyłości jest nadmiar energii dostarczany do organizmu wraz z pożywieniem. Przeciętny Polak nie wie, jakie jest jego zapotrzebowanie kaloryczne, i często dostarcza do organizmu zbyt dużą liczbę kilokalorii, najczęściej w postaci węglowodanów, o wysokim indeksie glikemicznym. Aby organizm prawidłowo funkcjonował, należy zjadać od trzech do pięciu posiłków dziennie, w odpowiednich odstępach czasu i z odpowiednim rozłożeniem ilości energii na poszczególne posiłki (Jarosz, 2017).

Regularne odstępy między posiłkami są bardzo istotne, ponieważ w organizmie nie dochodzi wówczas do gwałtownych wahań poziomu glukozy, a w konsekwencji uzyskanie prawidłowej masy ciała staje się znacznie łatwiejsze. Zaleca się, aby przerwy między posiłkami, w zależności od ich liczby, wynosiły od trzech do sześciu godzin (Świderska, 2012). Śniadanie powinno być spożyte 1-2 godziny od momentu wstania, natomiast kolację należy zjeść nie później niż dwie godziny przed snem (Jarosz, 2017).

Zdarza się jednak, że ludzie nie odżywiają się zgodnie z zasadami racjonalnego żywienia - najczęściej sytuacja ta dotyczy spotkań ze znajomymi, oglądania telewizji, przebywania w miejscach, w których znajduje się dużo jedzenia, a dostęp do niego jest łatwy (Pietrzykowska i Wierusz-Wysocka, 2008).

Aktywność fizyczna powinna odgrywać ważną rolę w życiu każdego człowieka, ponieważ odpowiada za prawidłowe funkcjonowanie organizmu. Bardzo często zdarza się jednak, że jedyną formą aktywności fizycznej dzieci są zajęcia wychowania fizycznego w szkole. Słyszy się też coraz częściej o nagminnych zwolnieniach dzie- 
ci z tego przedmiotu. W świecie nowych technologii i powszechnego dostępu do telewizji (w tym reklam) czy Internetu coraz trudniejsze jest zachęcenie dzieci do jakiejkolwiek aktywności fizycznej. Siedzący tryb życia znacznie wpływa na zmiany zachodzące w organizmie człowieka. Czas spędzany przed telewizorem czy komputerem wiąże się często z większym spożyciem żywności, najczęściej niezdrowej: fast foodów, słodyczy, słonych przekąsek (Jarosz, Wolnicka i Kłosowska, 2011).

$\mathrm{Z}$ badań ankietowych przeprowadzonych w roku 2018 przez Centrum Badania Opinii Społecznej (Aktywność fizyczna Polaków, 2018) dotyczących aktywności fizycznej osób powyżej 18 roku życia, zamieszkujących zarówno wsie, jak i duże miasta, z wykształceniem od podstawowego do wyższego, wynika, że $39 \%$ ankietowanych w ciagu całego roku nie uprawiało żadnego sportu. Co ciekawe, w roku 2013 takiej odpowiedzi udzieliło 3\% respondentów, a więc można przypuszczać, że średnio co roku 1\% Polaków zaprzestaje aktywności fizycznej.

Kolejnym czynnikiem niekorzystnie wpływającym na nadmierny przyrost masy ciała jest znany powszechnie marketing przemysłu spożywczego. Na każdym kroku ludzie osaczani są reklamami niezdrowej żywności. Producenci kierują swoje kampanie reklamowe głównie do dzieci (Jarosz i in., 2011). Wykorzystywanie do propagowania niezdrowej żywności bohaterów ze świata bajek, filmów i celebrytów jest manipulacją. Dziecko, widząc, że jego ulubiona postać poleca dany produkt, samo też pragnie go posiadać (Mazur i in., 2006). Jeśli chodzi o wpływ reklamy na osoby dorosłe, to powszechne jest zjawisko oferowania im atrakcyjnych gadżetów w zestawie, promocji typu $2+1$ (jeśli kupi się dwa produkty, trzeci dostanie się gratis), a także konkursów z nagrodami. Wszystkie te metody służą przyciągnięciu potencjalnego klienta, przez co chętniej sięga on po reklamowane, najczęściej niezdrowe produkty spożywcze.

Wśród czynników środowiskowych również mających wpływ na przyrost masy ciała jest długość snu. Nieodpowiednia liczba godzin snu (poniżej 6 lub powyżej 8 godzin) zwiększa ryzyko częstszego wyboru żywności posiadającej wysoką gęstość energetyczną (Białkowska, 2011). Badania przeprowadzone wśród 422 dzieci kaukaskich w wieku 5-10 lat w ramach projektu "Québec en Forme” (Chaput, Brunet i Tremblay, 2006) wykazały, że zarówno zbyt krótki, jak i zbyt długi sen był powiązany z występowaniem nadwagi i otyłości.

\section{Rodzaje otyłości i metody ich oceny}

Otyłość w zależności od przyczyn jej powstawania oraz miejsca występowania tkanki tłuszczowej klasyfikuje się następująco (Juruć i Bogdański, 2010, 2011):

- ze względu na przyczyny powstawania otyłości:

- otyłość prosta (pokarmowa), która rozwija się w momencie, gdy do organizmu długotrwale dostarczanych jest więcej kilokalorii, niż wynosi zapotrzebowanie energetyczne człowieka; ich nadmiar zostaje zmagazynowany w postaci tkanki tłuszczowej; 
- otyłość wtórna, która najczęściej pojawia się na skutek innej choroby; wpływają na nią czynniki genetyczne; może się rozwinąć także wskutek zażywania niektórych środków farmakologicznych;

- ze względu na rozłożenie tkanki tłuszczowej w organizmie:

- otyłość uogólniona - charakteryzuje się rozmieszczeniem tłuszczu w całym ciele,

- otyłość androidalna - tkanka tłuszczowa gromadzi się na brzuchu; otyłość tego typu występuje głównie u mężczyzn;

- otyłość gynoidalna - tkanka thuszczowa gromadzi się na pośladkach i udach; tego typu otyłość dotyczy częściej osób płci żeńskiej.

Metody diagnozowania otyłości dzieli się na proste i zaawansowane (WHO, 1999). Do metod prostych zalicza się: wskaźnik Queteleta, wskaźnik masy ciała BMI (Body Mass Index); wskaźnik WHR (Waist-Hip-Ratio); pomiar obwodu talii (Waist Circumference, WC). Do metod zaawansowanych natomiast zalicza się: tomografię komputerową $\mathrm{z}$ oceną planimetryczna, metody izotopowe, metody sonograficzne (USG), bioimpedancję elektryczną. Metody o zaawansowanej formule są wykorzystywane znacznie rzadziej niż metody proste ze względu na wysoki koszt wykonania badań.

Podstawową metodą badania stopnia zaawansowania otyłości jest wskaźnik BMI, za pomocą którego określa się, czy stosunek masy ciała do wzrostu jest prawidłowy (Szymocha, Bryła i Maniecka-Bryła, 2009). BMI u dzieci wyznaczany jest tak samo, jednakże wyniki porównywane są z siatkami centylowymi, na których znajdują się konkretne przedziały wiekowe (Waksmańska i Stolpa, 2018). Wartość tego wskaźnika obliczana jest na podstawie wzoru: BMI $\left(\mathrm{kg} / \mathrm{m}^{2}\right)=\frac{\text { masa ciała }(\mathrm{kg})}{\operatorname{wzrost}(\mathrm{m})}$

Tabela 1. Klasyfikacja nadwagi i otyłości w odniesieniu do BMI

Table 1. Classification of overweight and obesity concerning BMI

\begin{tabular}{|l|l|}
\hline \multicolumn{1}{|c|}{ BMI } & \multicolumn{1}{c|}{ Klasyfikacja/Classification } \\
\hline$<18,5$ & niedowaga/underweight \\
\hline $18,5-24,99$ & prawidłowa masa ciała/correct body weight \\
\hline $25,0-29,99$ & nadwaga/overweight \\
\hline $30,0-34,99$ & otyłość I stopnia/I degree obesity \\
\hline $35,0-39,99$ & otyłość II stopnia/II degree obesity \\
\hline$\geq 40,0$ & otyłość III stopnia/III degree obesity \\
\hline
\end{tabular}

Źródło: (Juruć i Bogdański, 2010).

Source: (Juruć i Bogdański, 2010).

W celu określania typu otyłości wykorzystuje się wskaźnik WHR. Wyznacza się go na podstawie wzoru WHR $=\frac{\text { obwód talii w najszerszym miejscu }(\mathrm{cm})}{\text { obwód bioder w najszerszym miejscu }(\mathrm{cm})}$. 
Określa on, czy mamy do czynienia $\mathrm{z}$ otyłością androidalną (WHR $>0,8$ dla kobiet, WHR $>1$ dla mężczyzn), czy gynoidalną (WHR $<0,8$ dla kobiet, WHR $<1$ dla mężczyzn) (Pietrzykowska i Wierusz-Wysocka, 2008). Jest on uzupełnieniem wskaźnika BMI.

Tabela 2. Interpretacja wyników pomiaru obwodu talii

Table 2. Interpretation of waist circumference measurement results

\begin{tabular}{|l|l|l|}
\hline \multicolumn{1}{|c|}{ Mężczyźni/Men } & \multicolumn{1}{|c|}{ Kobiety/Women } & \multicolumn{1}{c|}{$\begin{array}{l}\text { Interpretacja wyników/ } \\
\text { Results interpretation }\end{array}$} \\
\hline $\begin{array}{l}\text { Mniej niż } 94 \mathrm{~cm} / \\
\text { Less than } 94 \mathrm{~cm}\end{array}$ & $\begin{array}{l}\text { mniej niż } 80 \mathrm{~cm} / \\
\text { less than } 80 \mathrm{~cm}\end{array}$ & $\begin{array}{l}\text { waga normalna/ } \\
\text { normal weight }\end{array}$ \\
\hline $94-102 \mathrm{~cm}$ & $80-88 \mathrm{~cm}$ & nadwaga/overweight \\
\hline $\begin{array}{l}\text { Więcej niż } 102 \mathrm{~cm} / \\
\text { More than } 102 \mathrm{~cm}\end{array}$ & $\begin{array}{l}\text { więcej niż } 88 \mathrm{~cm} / \\
\text { more than } 88 \mathrm{~cm}\end{array}$ & $\begin{array}{l}\text { otyłość/ } \\
\text { obesity }\end{array}$ \\
\hline
\end{tabular}

Źródło: opracowanie własne na podstawie (Szymocha, Bryła i Maniecka-Bryła, 2009).

Source: own study based on (Szymocha, Bryła i Maniecka-Bryła, 2009).

Ostatnią z trzech najczęściej używanych metod oceny otyłości jest pomiar obwodu talii, za pomocą którego określa się otyłość uogólnioną (tab. 2).

\section{Skutki otyłości}

Nadmierna ilość tkanki tłuszczowej w organizmie prowadzi do różnego rodzaju powikłań zdrowotnych. Wśród nich najczęściej wyróżnia się:

- Miażdżyce - jest to choroba związana ze zwężaniem tętnic w wyniku nagromadzenia się cholesterolu. Jej rozwój następuje w momencie niedostatecznego zaopatrzenia w krew i tlen takich narządów, jak nerki, serce, mózg i kończyny (Cardiovascular disability..., 2010). Jest chorobą, która długo nie daje o sobie znać i rozwija się powoli, doprowadzając do niedotlenienia narządów. Powiązana $\mathrm{z}$ nią jest niedokrwienna choroba serca, będąca skutkiem niedostarczenia odpowiedniej ilości krwi, a tym samym tlenu do serca. Na tę chorobę umiera średnio 70-80\% pacjentów spośród osób chorujących na otyłość (Szymocha i in., 2009).

- Cukrzycę typu II - charakteryzuje się ona niewydolnością komórek beta oraz zmniejszoną insulinowrażliwością, powiązaną ze schorzeniem insulinooporności (Czupryniak, 2007).

- Nadciśnienie tętnicze - występuje, gdy wartość mierzonego ciśnienia skurczowego wynosi $140 \mathrm{~mm} \mathrm{Hg}$ lub przekracza tę wartość i wartości ciśnienia rozkurczowego są większe od $90 \mathrm{~mm} \mathrm{Hg}$ lub równe tej wartości.

- Obturacyjny bezdech senny - chorujących na tę przypadłość aż w 70\% stanowią osoby ze stwierdzoną otyłością. Bezdech senny polega na powtarzających się 
epizodach przerw w oddychaniu wynoszących ponad 10 sekund, wraz z sennością w ciągu dnia i dysfunkcją układu krążeniowo-oddechowego (Hasiec, Szumowski i Walczak, 2012).

- Choroby nowotworowe - m.in.: piersi, nerek, wątroby, jelita grubego, szyjki macicy, pęcherzyka żółciowego, pęcherza, przełyku, trzustki i tarczycy (Jaworski, Binda i Tarnowski, 2015).

- Depresję - niejednokrotnie spowodowaną negatywnym postrzeganiem przez społeczeństwo i negatywną samooceną. Zły nastrój towarzyszący stanom depresyjnym przyczynia się do jeszcze większego zniechęcenia do wszelkiego rodzaju aktywności fizycznej (Bąk-Sosnowska, 2009).

- Zespół kompulsywnego jedzenia - wiąże się on z bardzo niską samooceną osób chorujących i nasila objawy depresji. Geneza tego schorzenia cechuje się niepohamowanym spożywaniem pożywienia bez względu na jego ilość i jakość (Brytek-Matera i Charzyńska, 2009).

\section{Nadwaga i otyłość mieszkańców Polski}

Otyłość jest chorobą cywilizacyjną rozpowszechnioną na dużą skalę, również w Polsce.

Według danych zamieszczonych w raporcie Sustainable development solutions network (Sachs i in., 2019) poziom otyłości w roku 2019 w Polsce wśród osób dorosłych wynosił 23,1\% (rys. 1). Wyższy wskaźnik otyłości wykazano u osób zamieszkujących Maltę, gdzie aż 28,9\% społeczeństwa cierpi na otyłość, czy też Wielką Brytanię, w której otyłość dotyka 27,8\% społeczeństwa. Otyłość mieszkańców Polski jest porównywalna z poziomem otyłości mieszkańców Luksemburga.

Jeśli chodzi o problem nadwagi wśród dorosłych mieszkańców Europy, to z danych Eurostatu (rys. 2) wynika, że ponad połowa polskiego społeczeństwa w roku 2017 zmagała się z nadwagą (56\%). Jest więc bardzo prawdopodobne, że tak wysoki poziom nadwagi pociaggnie za sobą procentowy wzrost liczby osób otyłych. Należy zaznaczyć, iż w większości krajów europejskich poziom nadwagi wśród osób dorosłych przekraczał 50\%. W tym zestawieniu do krajów z najwyższym poziomem nadwagi należą mieszkańcy Rumunii, Czech i Malty. Najniższy wskaźnik nadwagi (poniżej 50\%) mają jedynie mieszkańcy Belgii, Francji, Luksemburga i Niderlandów.

Otyłość w Polsce w latach 2011-2016 wykazywała tendencję wzrostową (Sachs i in., 2019). W roku 2018 nastapił nieznaczny jej spadek, który utrzymywał się na tym samym poziomie również w roku 2019 (rys. 3). Fakt, że liczba Polaków zmagających się z otyłością nieznacznie się zmniejszyła, nie jest powodem do zadowolenia. Może jedynie wskazywać na wzrost świadomości ludności odnośnie do zagrożeń spowodowanych nadmierną masą ciała. 


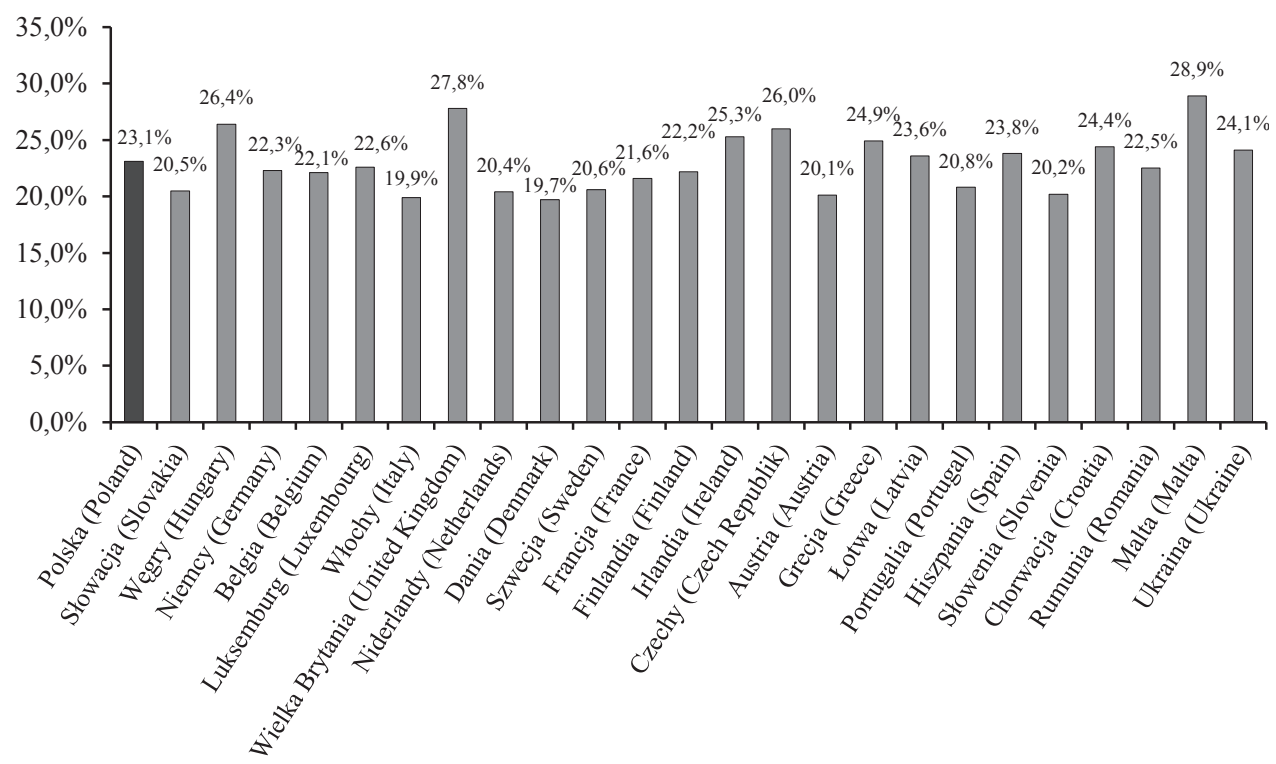

Rys. 1. Procent populacji dorosłych z otyłością w krajach Europy

Fig. 1. Percentage of the adult population with obesity in European countries

Źródło: opracowanie własne na podstawie (Sachs i in., 2019).

Source: own study based on (Sachs i in., 2019).

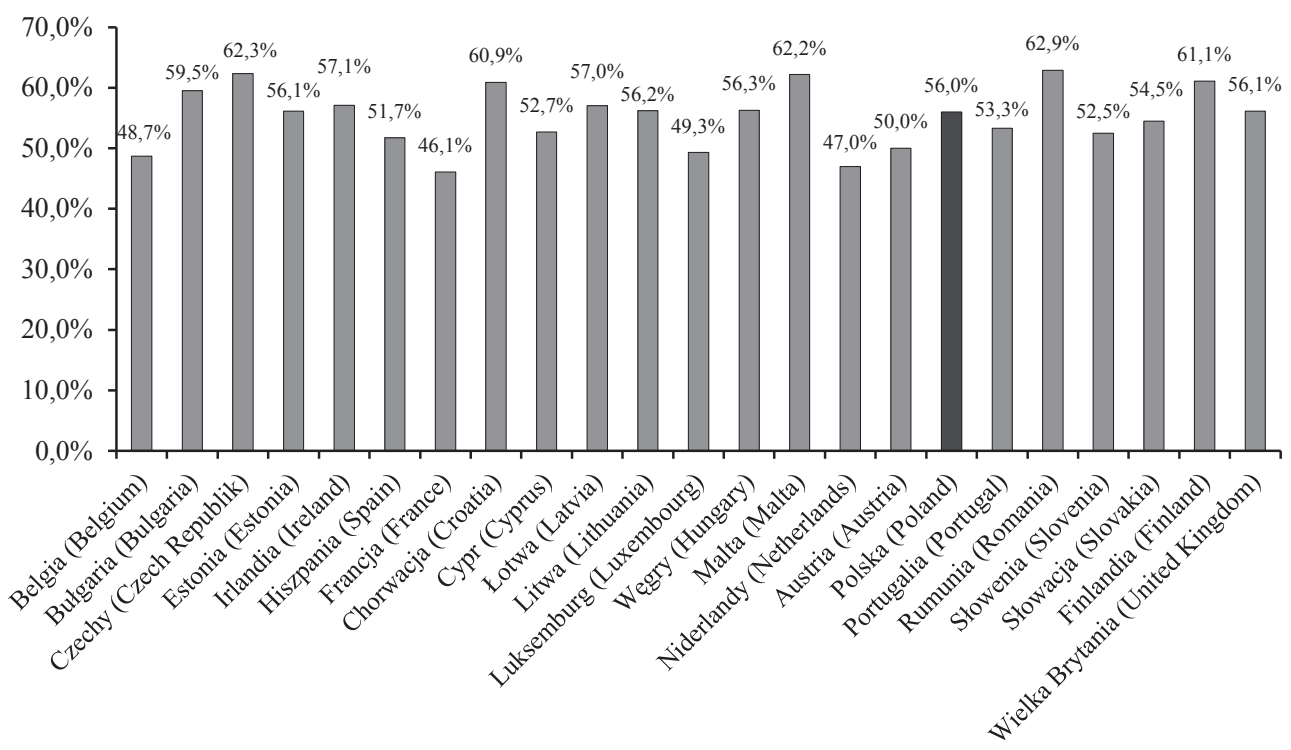

Rys. 2. Procentowy wskaźnik nadwagi wśród osób dorosłych w krajach Europy

Fig. 2. Percentage of adult overweight in European countries

Źródło: opracowanie własne na podstawie (Eurostat, b.d.).

Source: own study based on (Eurostat, b.d.). 


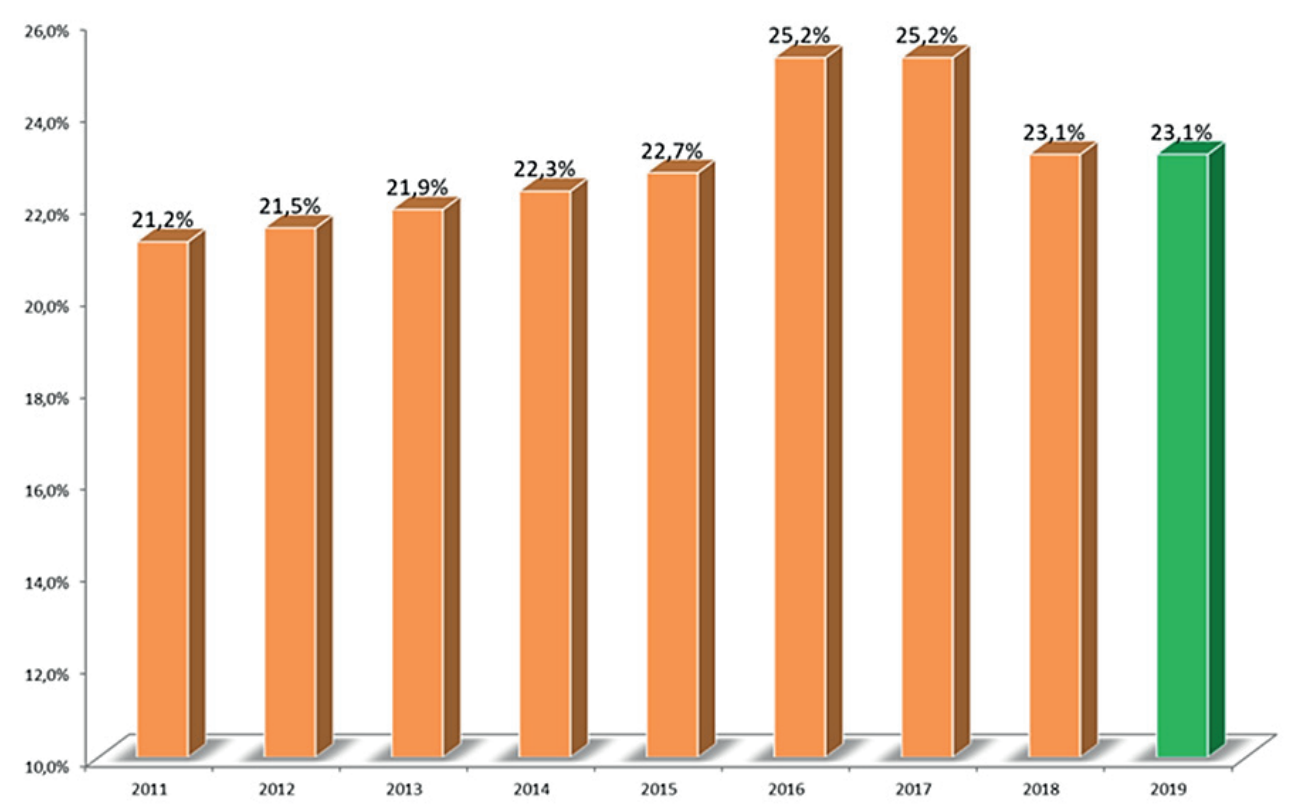

Rys. 3. Procent osób otyłych wśród dorosłych mieszkańców Polski w latach 2011-2019

Fig. 3. Percentage of obese people among adult inhabitants of Poland in 2011-2019

Źródło: opracowanie własne na podstawie (Sachs i in., 2019).

Source: own study based on (Sachs i in., 2019).

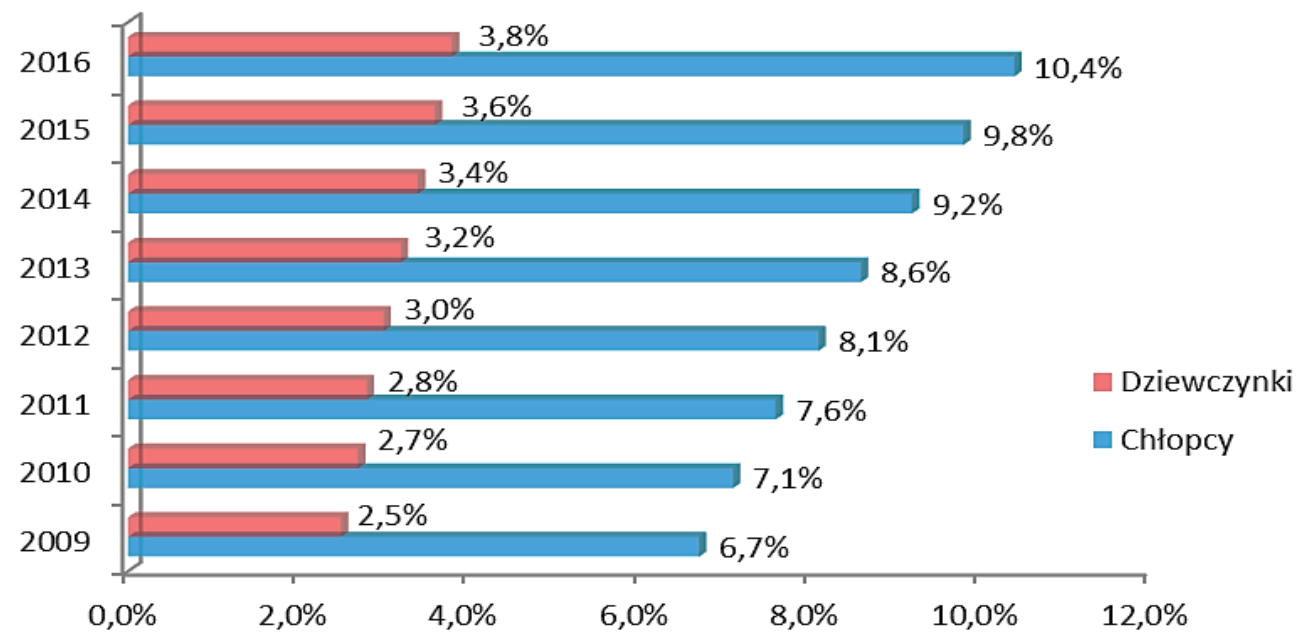

Rys. 4. Otyłość wśród polskich dzieci i młodzieży w wieku 10-19 lat w latach 2009-2016

Fig. 4. Obesity among Polish children and adolescents aged 10-19 in the years 2009-2016

Źródło: opracowanie własne na podstawie (WHO, b.d.).

Source: own study based on (WHO, b.d.). 
Również statystyki związane z poziomem nadwagi i otyłości wśród dzieci i młodzieży w Polsce są bardzo niepokojące. Badanie przeprowadzone przez Światową Organizację Zdrowia w latach 2009-2016 wskazuje na tendencję wzrostową zachorowalności z powodu nadwagi i otyłości wśród dzieci (WHO, b.d.). Dane na rys. 4 i 5 wykazują, że problemy z nadmierną masą ciała częściej dotyczą chłopców niż dziewcząt. W ciagu siedmiu lat u chłopców odnotowano wzrost otyłości o 3,7\%, natomiast u dziewczynek - o 1,3\%. Odsetek dzieci z nadwagą był jeszcze wyższy, ponieważ jego wzrost wyniósł odpowiednio $6,4 \%$ u chłopców i 3,6\% u dziewcząt.

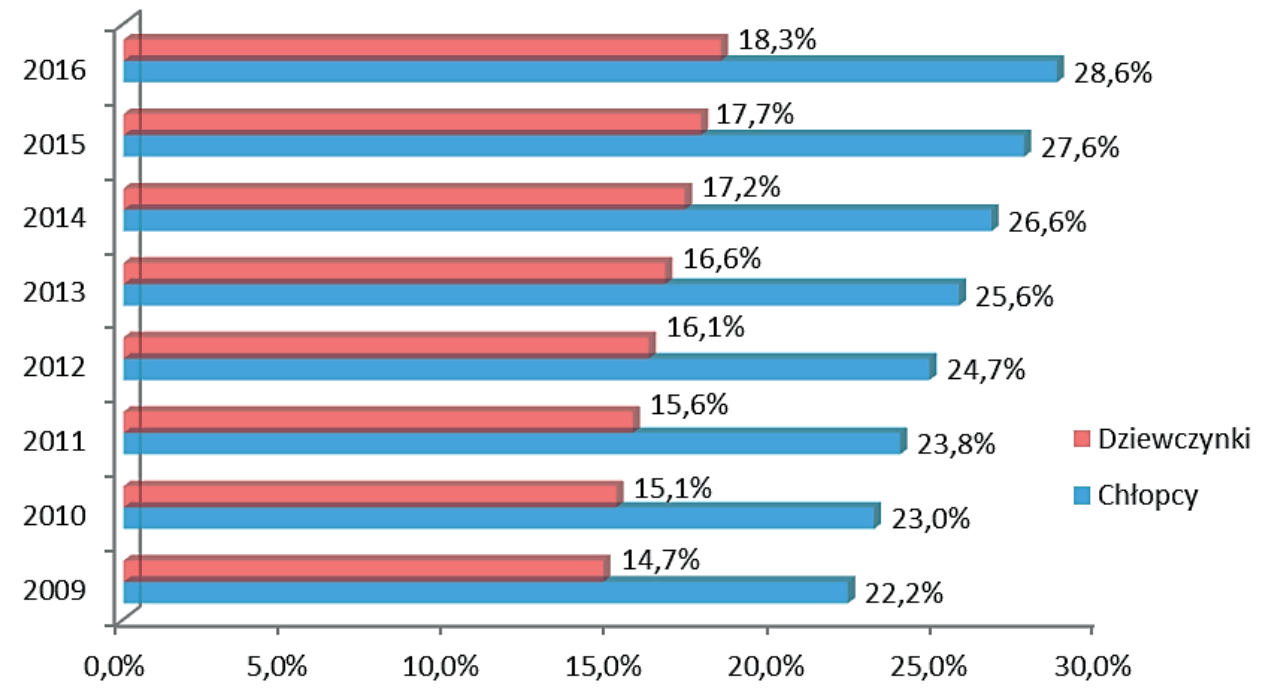

Rys. 5. Nadwaga wśród polskich dzieci i młodzieży w wieku 10-19 lat w latach 2009-2016

Fig. 5. Overweight among Polish children and adolescents aged 10-19 in the years 2009-2016

Źródło: opracowanie własne na podstawie (WHO, b.d.).

Source: own study based on (WHO, b.d.).

Przedstawione wyniki badań wykazują, że skala problemu nadwagi i otyłości wśród społeczeństwa polskiego jest ogromna. Patrząc na informacje dotyczące otyłości, można stwierdzić, że otyłość słusznie określana jest mianem epidemii. Wiąże się ona nie tylko z pogorszeniem stanu zdrowia czy szybszą umieralnością, ale także ze zwiększeniem kosztów leczenia tej choroby i innych jednostek chorobowych $\mathrm{z}$ nią powiązanych.

\section{Metody walki z otyłością}

Otyłość można rozpoznać w łatwy sposób, natomiast jej leczenie, uzależnione przede wszystkim od podejścia samego pacjenta, jest bardzo trudne (Przybylska, Kurowska i Przybylski, 2012). Jeżeli osoba chorująca nie będzie miała w sobie siły 
walki i determinacji do wyleczenia, to namawianie jej do jakichkolwiek zmian nie przyniesie efektu. Pomoc osobom otyłym wymaga dużo cierpliwości i zaangażowania w zwalczanie choroby. Wśród metod leczenia otyłości wyróżnia się m.in.: odpowiednio dobraną dietę, modyfikację zachowań, aktywność fizyczną, farmakoterapię, leczenie chirurgiczne.

Pierwszą i podstawową metodą stosowaną w leczeniu otyłości jest zastosowanie diety indywidualnie dobranej do każdego pacjenta. Przy jej doborze należy pamiętać o uwzględnieniu wszystkich czynników mających wpływ na dotychczasowy stan zdrowia, m.in. przebyte lub aktualne choroby, poziom aktywności fizycznej, a także przyzwyczajenia żywieniowe (Tsigos i in., 2009). Każda dieta, mająca na celu zredukowanie tkanki tłuszczowej, musi opierać się przede wszystkim na zredukowaniu ilości dostarczanej energii. W szczególności powinno się ograniczyć spożywanie produktów zawierających dużą ilość tłuszczów (głównie w postaci nasyconych kwasów thuszczowych) i węglowodanów o wysokim indeksie glikemicznym i zastąpić je produktami bogatymi w błonnik pokarmowy oraz węglowodany o niskim indeksie glikemicznym (Czupryniak, 2007).

Leczenie otyłości powinno się odbywać pod nadzorem lekarza, dietetyka i jeśli zachodzi taka potrzeba - psychologa. Pacjent powinien się zastosować do kilku zasad. Przede wszystkim unikać podjadania między posiłkami, wyeliminować żywność typu fast food, zmniejszyć wielkość racji pokarmowych i jeść w określonych odstępach czasu, nie zapominając o najważniejszym posiłku w ciągu dnia, czyli śniadaniu. Według badań przeprowadzonych w roku 2017 w ramach ogólnopolskiej kampanii społecznej „Myślę zdrowo, żyję w równowadze” przez Instytut Psychodietetyki i Mixit (Mixit, b.d.) wynika, że 73\% badanych spośród osób, które zadeklarowały, że odżywiają się żywnością typu fast food, wychodzi z domu, nie jedząc śniadania, a nieregularne spożywanie posiłków sprzyja częstszemu sięganiu po „szybkie jedzenie” i wszelkiego rodzaju przekąski.

Skuteczne sposoby pomagające we wprowadzaniu nowych zasad dla chorego stanowią (Sattar i Lean, 2009):

- używanie zastawy w mniejszych rozmiarach niż dotychczas,

- chodzenie na zakupy po posiłkach,

- robienie zakupów spożywczych z listą,

- prowadzenie dziennika, w którym zostaną zawarte dane na temat: godziny, rodzaju produktów i ich ilości, liczby konsumowanych posiłków,

- unikanie zachowań, które rozpraszają uwagę podczas jedzenia (używanie telefonu, oglądanie telewizji),

- wyeliminowanie spożywania posiłków poza domem.

Zwiększenie poziomu aktywności fizycznej pozwala na zredukowanie tkanki tłuszczowej i zastąpienie jej masą mięśniowa, sprawiając jednocześnie, że sylwetka wygląda korzystniej. Aktywność fizyczna niesie ze sobą wiele korzyści, m.in.: skutecznie podnosi samoocenę i wpływa na pozytywne postrzeganie siebie, jednocześnie zmniejszając ryzyko chorób, np. depresji. Wpływa na prawidłowe działanie organizmu i oddziałuje na poprawę wydolności. Osobom chorującym na otyłość za- 
leca się wprowadzenie zmian w swoim trybie życia, np. zastapienie środków komunikacji niewymagających wysiłku fizycznego takimi formami ruchu, jak spacery czy jazda na rowerze. Każdy rodzaj aktywności musi być dostosowany do pacjenta indywidualnie, w zależności od jego predyspozycji i stanu zdrowia. Poziom aktywności powinien być stopniowo zwiększany (Tsigos i in., 2009). Przez pojęcie aktywności fizycznej rozumie się każdą czynność ruchową, dlatego też można ją podzielić na wykonywaną codziennie (np. wchodzenie po schodach, spacery) oraz zaplanowaną (np. ćwiczenia na siłowni pod nadzorem trenera personalnego). Uprawianie każdego rodzaju aktywności fizycznej ma pozytywne skutki dla samopoczucia i zdrowia człowieka (Plewa i Markiewicz, 2006).

Warto zwrócić uwagę, iż obecnie, w dobie nowoczesnych technologii, istnieją różnego rodzaju aplikacje i gadżety pomagające w kontrolowaniu tętna, kalorii traconych podczas ćwiczeń czy też przebytego dystansu. Ich wykorzystanie może być motywatorem zmian pozwalających na bieżąco śledzić postępy osób wykonujących aktywność fizyczną.

Farmakoterapia powinna stanowić jedynie uzupełnienie uprzednio wymienionych metod i nie powinna być stosowana u wszystkich osób. Zaleca się przyjmowanie leków osobom, które borykają się, prócz otyłości, także z innymi schorzeniami chorobowymi, np. cukrzycą typu II (Tsigos i in., 2009). Skuteczność lekoterapii jest zależna od zmian wprowadzonych w życie, dotyczących aktywności fizycznej oraz prawidłowego doboru diety. Jeśli zastosowanie leków w ciagu 3-6 miesięcy nie przyniesie pożądanych efektów utraty masy ciała o 5-10\%, oznacza to, że leczenie farmakologiczne jest nieskuteczne (Sattar i Lean, 2009).

W najbardziej zaawansowanym stadium otyłości, gdy BMI $>40$, czasami też w przypadku otyłości II stopnia, stosowane jest leczenie chirurgiczne. Zabiegi chirurgiczne mogą zostać przeprowadzone u osób, które ukończyły 18 lat i mają nie więcej niż 60 lat (Paśnik i Kostewicz, 2006).

Do mniej inwazyjnych metod leczenia chirurgicznego należą metody laparoskopowe. Wśród nich wyróżnia się (Sattar i Lean, 2007):

- nadmuchiwaną opaskę żołądkową - operacja polega na umieszczeniu opaski w górnej części żołądka, w taki sposób, aby obejmowała 5\% jego powierzchni; lekarz może kontrolować średnicę opaski; po założeniu opaski przez 12-18 miesięcy należy stawiać się na wizyty kontrolne co miesiąc,

- ominięcie żołądkowo-jelitowe - ma na celu wydzielenie z żołądka „zbiorniczka” o pojemności $15 \mathrm{~cm}^{3}$, a następnie zespolenie go z jelitem cienkim; przez 12 miesięcy po operacji należy zgłaszać się na kontrole co 3 miesiące.

\section{Podsumowanie}

Problem otyłości stanowi ogromne ryzyko dla zdrowia i życia człowieka. Powikłania występujące przy nadmiernej masie ciała to kwestia dotycząca wszystkich ludzi, niezależnie od wieku, statusu społecznego, koloru skóry i płci. W patogenezie otyło- 
ści istnieją dwa czynniki odgrywające istotną rolę w jej rozwoju, a mianowicie nadmierna podaż energii w postaci wysokokalorycznych posiłków złożonych z produktów przetworzonych, bogatych $\mathrm{w}$ węglowodany proste, oraz niski poziom aktywności fizycznej. Osoby chorujące na otyłość w celu ograniczania jej dalszego rozwoju wymagają zmian nawyków żywieniowych, stylu życia bądź też leczenia farmakologicznego, a w niektórych przypadkach nawet operacyjnego.

Raporty dotyczące poziomu otyłości w Polsce i innych krajach europejskich wskazują, iż coraz więcej osób zmaga się z nadmierną masą ciała. Poziom otyłości na świecie wśród osób dorosłych rośnie, choć na przełomie lat 2017 i 2018 w Polsce odnotowano nieznaczny spadek liczby osób z nadwagą i otyłością, który utrzymywał się również w roku 2019. Może to świadczyć o zwiększeniu świadomości społeczeństwa polskiego odnośnie do zagrożeń, jakie powoduje nadmierna masa ciała. W Polsce z każdym rokiem przybywa jednak otyłych dzieci. Problem ten częściej dotyczy chłopców. Można więc uznać, że otyłość słusznie określana jest mianem epidemii XXI wieku.

\section{Literatura}

Aktywność fizyczna Polaków (2018). Komunikat z badań CBOS nr 125/2018, 2.

Bąk-Sosnowska, M. (2009). Miejsce psychologa w leczeniu otyłości. Forum Medycyny Rodzinnej, 3(4), 297-303.

Białkowska, M. (2011). Etiopatogeneza otyłości. Postępy Nauk Medycznych, XXIV, (9), 768.

Brytek-Matera, A. i Charzyńska, E. (2009). Poznawcze i behawioralne determinanty zaburzeń odżywiania u kobiet z otyłością. Endokrynologia, Otyłość i Zaburzenia Przemiany Materii, 5, (2), 45-50.

Cardiovascular disability: Updating the social security listings. (2010). Washington: Committee on Social Security Cardiovascular Disability Criteria, IOM (Institute of Medicine).

Chaput, J.-P., Brunet, M. i Tremblay, A. (2006). Relationship between short sleeping hours and childhood overweight/obesity: Results from the "Quebec en Forme" Project. International Journal of Obesity, (3), 1080-1085.

Czerwińska, E., Walicka, M. i Marcinowska-Suchowierska, E. (2013). Otyłość - czy zawsze prosta? Postęy Nauk Medycznych, XXVI, (4), 307-310.

Czupryniak, L. (2007). Beta-protekcja - patofizjologiczny element terapii cukrzycy typu 2. Diabetologia Praktyczna, 8, B11.

Eurostat. (b.d.). Pobrano 17 stycznia $2020 \mathrm{z}$ https://ec.europa.eu/eurostat/tgm/table.do?tab=table\& init=1\&plugin=1\&language

Hasiec, A., Szumowski, Ł. i Walczak, F. (2012). Obturacyjny bezdech - senny zabójca. Forum Medycyny Rodzinnej, 6(3), 103-114.

Jarosz, M. (red.). (2017). Normy żywienia dla populacji Polski. Warszawa: Instytut Żywności i Żywienia.

Jarosz, M., Wolnicka, K. i Kłosowska, J. (2011). Czynniki środowiskowe związane z występowaniem nadwagi i otyłości wśród dzieci i młodzieży. Postępy Nauk Medycznych, XXIV, (9), 770-777.

Jaworski, P., Binda, A. i Tarnowski, W. (2015). Wpływ otyłości na rozwój choroby nowotworowej. Postęy Nauk Medycznych, XXVIII, (9), 673-676.

Juruć, A. i Bogdański, P. (2010). Otyłość i co dalej? O psychologicznych konsekwencjach nadmiernej masy ciała. Forum Zaburzeń Metabolicznych, 1(4), 210-219. 
Juruć, A. i Bogdański, P. (2011). Osobowość w rozmiarze XXL. Psychologiczne czynniki ryzyka otyłości. Forum Zaburzeń Metabolicznych, 2(1), 34.

Kłósek, P. (2016). Zależności między stresem psychologicznym a powstawaniem otyłości. Forum Medycyny Rodzinnej, 10(3), 145-152.

Mazur, A., Szymanik, I., Matusik, P. i Małecka-Tendera, E. (2006). Rola reklam i mediów w powstawaniu otyłości u dzieci i młodzieży. Endokrynologia, Otyłość i Zaburzenia Przemiany Materii, 2(1), 18-21.

Mixit. (b.d.). Pobrano 15 stycznia $2020 \mathrm{z}$ https://www.mixit.pl/press/zyjewrownowadze

Morawska, E., Kulczycka, K., Stychno, E., Grochowski, L. i Kosicka, B. (2015). Czynniki motywujące osoby otyłe w procesie odchudzania. Probl Hig Epidemiol, 96(1), 293-297.

Ogińska-Bulik, N. (2004). Psychologia nadmiernego jedzenia. Łódź: Wydawnictwo Uniwersytetu Łódzkiego.

Ogińska-Bulik, N. (2007). Pułapki jedzenia. Style i Charaktery, (2), 14-16.

Paśnik, K. i Kostewicz, W. (2006). Laparoskopowe leczenie otyłości. Postępy Nauk Medycznych, (1), 27-35.

Pietrzykowska, E. i Wierusz-Wysocka, B. (2008). Psychologiczne aspekty nadwagi, otyłości i odchudzania się. Pol. Merk. Lek., XXIV, (143), 472-476.

Plewa, M. i Markiewicz, A. (2006). Aktywność fizyczna w profilaktyce i leczeniu otyłości. Endokrynologia, Otyłość i Zaburzenia Przemiany Materii, 2(1), 30-37.

Przybylska, D., Kurowska, M. i Przybylski, P. (2012). Otyłość i nadwaga w populacji rozwojowej. Hygeia Public Health, 47(1), 28-35.

Sachs, J., Schmidt-Traub, G., Kroll, C., Lafortune, G. i Fuller, G. (2019). Sustainable development report. New York. Pobrano z https://www.sdgindex.org/reports/sustainable-development-report-2019

Sattar, N. i Lean, M. (2009). ABC of obesity. Oxford: Blackwell Publishing Ltd.

Szymocha, M., Bryła, M. i Maniecka-Bryła, I. (2009). Epidemia otyłości w XXI wieku. Zdr. Publ., $119(2), 207-212$.

Świderska, M. (2012). Rodzinne i genetyczne uwarunkowania otyłości. Pedagogika Rodziny, 2(1), 101-111.

Tsigos, C., Hainer, V., Basdevant, A., Finer, N., Fried, M., Mathus-Vliegen, E., Micic, D., Maximo Maislos, M., Roman, G., Schutz, Y., Toplak, H. i Zahorska-Markiewicz, B. (2009). Postępowanie w otyłości dorosłych: europejskie wytyczne dla praktyki klinicznej. Endokrynologia, Otyłość i Zaburzenia Przemiany Materii, 5(3), 87-98.

Waksmańska, W. i Stolpa, B. (2018). Analiza wskaźnika BMI wybranej grupy dzieci w wieku 4 i 6 lat zamieszkałych na terenie miasta Cieszyn. Piel. Zdr. Publ., 8(2), 105-109.

WHO. (b.d). Pobrano 17 stycznia 2020 z https://www.who.int/gho/en/

WHO. (1999). Obesity: Preventing and managing the global epidemic (Technical report series no. 894). Geneva: WHO Consultation on Obesity. 